\title{
Pengaruh Shopping Lifestyle dan Positive Emotion Terhadap Impulse Buying
}

\author{
Pipih Sopiyan dan R. Neny Kusumadewi \\ Program Studi Manajemen FEB Universitas Majalengka \\ pipihoke@gmail.com \\ Kusumadewi.neny@gmail.com
}

\begin{abstract}
ABSTRAK
Tujuan dari penelitian ini adalah untuk mengetahui pengaruh Shopping Lifestyle dan Positive Emotion terhadap Impulse Buying baik secara parsial maupun secara simultan. Penelitian ini termasuk jenis penelitian survey dengan menggunakan pendekatan deskriptif dan verifikatif. Hasil penelitian menunjukan bahwa $75.48 \%$ konsumen bersikap Shopping Lifestyle , 75.45\% konsumen berada dalam kondisi Positive Emotion dan 75.39\% menunjukan perilaku Impulse Buying. Secara parsial Shopping Lifestyle berpengaruh positif dan signifikan terhadap Impulse Buying dengan tingkat kontribusi $13.76 \%$. Sementara, Positive Emotion tidak berpengaruh terhadap Impulse Buying dengan tingkat kontrbusi $1.88 \%$. Namun, secara simultan Shopping Lifestyle dan Positive Emotion berpengaruh signifikan terhadap Impulse Buying dengan tingkat kontribusi $15 \%$.
\end{abstract}

Kata kunci : Shopping Lifestyle, Positive Emotion, Impulse Buying

\begin{abstract}
The purpose of this study was to determine the effect of Shopping Lifestyle and Positive Emotion on Impulse Buying both partially and simultaneously. This research is a type of survey research using descriptive and verification approaches. The object of consumer research shop UD Putra Tiga Saudara Majalengka.The results showed that $75.48 \%$ of consumers behaved in Shopping Lifestyle, $75.45 \%$ of consumers were in Positive Emotion conditions and $75.39 \%$ showed impulse buying behavior. Partially Shopping Lifestyle has a positive and significant effect on Impulse Buying with a contribution rate of 13.76\%. Meanwhile, Positive Emotion has no effect on Impulse Buying with a contribution rate of 1.88\%. However, simultaneous Shopping Lifestyle and Positive Emotion have a significant effect on Impulse Buying with a contribution rate of $15 \%$. Seeing these results, it is important to do research again on the Positive Emotion variable.
\end{abstract}

Keywords : Shopping Lifestyle, Positive Emotion, Impulse Buying

\section{PENDAHULUAN}

Perkembangan pasar ritel saat ini begitu pesat, hal ini berdampak semakin tingginya persaingan dalam usaha. Perusahaan yang ingin berhasil dalam persaingan ini harus menguasai pasar. Salah satu aktivitas yang harus dilakukan dalam menguasai pasar adalah melalui aktivitas pemasaran yang baik yakni berfokus pada needs dan wants konsumen. Perusahaan harus mampu memenuhi needs dan wants konsumen .

Keberlanjutan suatu perusahaan khususnya perusahaan yang bergerak di bidang retail adalah tergantung pada bagaimana kemampuan perusahaan dalam mempengaruhi konsumen agar melakukan keputusan pembelian setinggi-tingginya. Keputusan pembelian yang dilandasi dengan kebutuhan merupakan hal yang seharusnya mampu diciptakan oleh perusahaan, namun fenomena yang terjadi sekarang ini ternyata banyak konsumen yang berkunjung dan melakukan keputusan pembelian terhadap produk-produk yang sebenarnya tidak direncanakan. Kondisi demikian, harus mampu di respon oleh perusahaaan sebagai peluang bisnis yang baru yang perlu dipelajari dan dikembangkan. Melalui pengembangan konsep Impulse Buying, perusahaan diharapkan mempunyai strategi baru yang perlu dikembangkan di masa yang akan datang.

Menurut Anwar Prabu Mangkunegara (2009: 4) perilaku konsumen adalah tindakan-tindakan yang dilakukan oleh individu atau organisasi yang berhubungan dengan proses pengambilan keputusan dalam mendapatkan, menggunakan barang-barang atau jasa ekonomi dapat dipengaruhi lingkungannya. namun adakala pembelian dilakukan begitu saja ketika konsumen melihat suatu produk. Tipe 
pembelian seperti ini disebut impulse buying atau pembelian tanpa yang tidak direncanakan sebelumnya. Menurut Utami dalam Anggi Mita Wijaya (2016: 190) pembelian implusif adalah pembelian yang terjadi ketika konsumen melihat produk atau merk tertentu, kemudian konsumen menjadi tertarik untuk membelinya, biasanya karena adanya rangsangan yang menarik dari toko tersebut. Impulse buying yang dilakukan oleh konsumen bukanlah hal yang baru dalam pemasaran, namun penjelasan mengapa hal tersebut bisa terjadi belum banyak diketahui oleh pebisnis. Oleh karena itulah pebisnis harus mempelajari hal-hal apa saja yang dapat memicu terjadinya impulse buying. Strategi ini dilakukan agar pebisnis dapat melakukan strategistrategi pemasaran selanjutnya untuk menjaring lebih banyak konsumen sehingga akan mendatangkan omzet yang banyak bagi perusahaan.

Rachmawati (2009 : 45) menyatakan bahwa ketika seseorang melakukan impulse buying bisa dipengaruhi oleh beberapa faktor, yaitu hedonic shopping value, shopping lifestyle, dan positive emotion. Betty Jackson dalam Edwin Japarianto dan Sugiono Sugiharto (2011: 33) mengatakan bahwa shopping lifestyle merupakan ekspresi tentang lifestyle dalam berbelanja yang mencerminkan perbedaan status sosial. Shopping lifestyle merupakan sikap atau pilihan seseorang dalam menggunakan atau menghabiskan uangnya untuk membeli suatu produk. Peningkatan pendapatan konsumen mengakibatkan kebutuhan konsumen juga ikut meningkat. Kebutuhan yang terus menerus-menerus meningkat menyebabkan tingkat belanja konsumen pun meningkat. Baik secara langsung maupun tidak langsung, dalam era globalisasi membawa masyarakat Indonesia ke dalam budaya yang konsumtif, dimana belanja sudah menjadi lifestyle mereka. Konsumen akan rela mengorbankan sesuatu demi mendapatkan produk yang mereka inginkan dan mereka senangi. Shopping lifestyle mengacu pada pola konsumsi yang mencerminkan pilihan seseorang tentang bagaimana cara menghabiskan waktu dan uang. Dalam arti ekonomi, shopping lifestyle menunjukan cara yang dipilih oleh seseorang untuk mengalokasikan pendapatan, baik dari segi alokasi dana untuk berbagai produk dan layanan, serta alternatif-alternatif tertentu dalam pembedaan kategori serupa.

Menurut Beatty \& Ferrel dalam Septian Wahyudi (2017) emosi sangat mempengaruhi tindakan impulse buying. Emosi merupakan keadaan testimulasi dari organisme, yang meliputi perubahan-perubahan, termasuk perubahan prilaku konsumen yang mempunyai mood positif akan lebih kondusif untuk melakukan pembelian implusif daripada konsumen yang suasana hatinya negatif. Emosi yang merasa senang dan bangga ketika berbelanja dapat mempengaruhi pembelian implusif. Tirmizi et al. dalam Mega Usvita (2016:72) positive emotion sendiri didefinisikan sebagai suasana hati yang mempengaruhi dan menentukan intensitas pengambilan keputusan konsumen. Premananto dalam Mega Usvita (2016: 72) Faktor perasaan atau emosi merupakan konstruk yang bersifat temporer karena berkaitan dengan situasi atau objek tertentu. Perasaan seperti jatuh cinta, gembira, ingin memiliki, terpesona, dan antusias dari berbagai studi disinyalir memiliki korelasi positif yang signifikan dengan kecenderungan melakukan impulse buying.

Objek penelitian akan dilakukan di toko UD Putra Tiga Saudara Majalengka, Toko UD Putra Tiga Saudara berdiri tahun 2001 dan membuka cabang baru di Desa Baribis Kecamatan Cigasong Kabupaten yang disahkan pada tanggal 25 April 2016. Toko UD Putra Tiga Saudara merupakan salah satu retail dan grosir yang bergerak dibidang bisnis fashion anakanak sampai dewasa, menyediakan peralatan bayi, kosmetik, tas, dan boneka.

Menurut hasil wawancara dengan bapak Yayan Suryana selaku Manager UD Putra Tiga Saudara pada tahun 2018, beliau mengatakan bahwa rata- rata peningkatan penjualan untuk setiap tahunnya mencapai $40 \%$ bahkan jika akan menghadapi Hari Raya Idul Fitri kenaikan bisa mencapai 50 - 60\%. UD Putra Tiga Saudara tidak memberlakukan sistem diskon atau promosi karena di lihat dari segi harga relatif murah dan bisa di jangkau mulai kalangan menengah ke bawah sampai menengah ke atas. Untuk menarik konsumen pihak perusahaan selalu update kepada konsumen dan pelanggan ketika barang baru telah datang dengan cara memberitahu lewat media sosial dan diteruskan dengan penyampaian mouth to mouth atau dari mulut ke mulut dengan begitu konsumen akan tertarik untuk berbelanja.

Berdasarkan hasil survey yang telah dilakukan pada bulan april 2018 ternyata hanya ada 30\% konsumen yang merencanakan apa yang akan di beli dan tidak membeli item tambahan yang akan dibeli, sebanyak $30 \%$ konsumen merencanakan apa yang akan dibeli tetapi membeli item tambahan tanpa direncanakan sebelumnya, dan sisanya $40 \%$ tidak merencanakan apa yang akan mereka beli. Dan hanya $40 \%$ responden menyatakan lebih suka berbelanja tanpa melakukan perencanaan terlebih dahulu. Maka dapat disimpulkan bahwa sebagian besar konsumen UD Putra Tiga Saudara melakukan impulse buying.

Konsumen yang melakukan perencanaan dan tidak membeli item tambahan diluar yang direncanakan biasanya memiliki waktu luang yang terbatas dan 
tidak membawa uang lebih untuk berbelanja, selain itu mereka mendisiplinkan diri mereka sehingga terbiasa untuk tidak membeli item tambahan. Hal tersebut berbanding terbalik dengan konsumen yang melakukan perencanaan sebelum berbelanja. Mereka menganggap berbelanja adalah hal yang menyenangkan dan bisa mengisi waktu luang, sambil belanja untuk pemenuhan kebutuhan. Sedangkan konsumen yang melakukan perencanaan sebelum berbelanja tetapi juga membeli item tambahan diluar perencanaan seringkali terstimulus oleh barang yang mereka suka di dalam toko.

Berdasarkan fenomena tersebut, penulis tertarik untuk melakukan penelitian dengan judul "Pengaruh Shopping Lifestyle dan Positive Emotion Terhadap Impulse Buying (Studi Pada Konsumen Toko UD Putra Tiga Saudara Majalengka)".

\section{Rumusan Masalah}

Berdasarkan latar belakang yang telah dikemukakan sebelumnya, maka dapat ditarik rumusan masalah sebagai berikut :

1. Bagaimana pengaruh shopping lifestyle terhadap impulse buying di Toko UD Putra Tiga Saudara Majalengka.

2. Bagaimana pengaruh positive emotion terhadap impulse buying di Toko UD Putra Tiga Saudara Majalengka.

3. Bagaimana pengaruh shopping lifestyle dan positive emotion terhadap impulse buying di Toko UD Putra Tiga Saudara Majalengka.

\section{Tujuan Penelitian}

Tujuan penelitian ini sebagai berikut :

1. Untuk mengetahui pengaruh Shopping Lifestyle terhadap Impulse Buying di Toko UD Putra Tiga Saudara Majalengka.

2. Untuk mengetahui pengaruh Positive Emotion terhadap Impulse Buying di Toko UD Putra Tiga Saudara Majalengka.

3. Untuk mengetahui pengaruh Shopping Lifestyle dan Positive Emotion terhadap Impulse Buying di Toko UD Putra Tiga Saudara Majalengka.

\section{KAJIAN PUSTAKA}

\section{Shopping Lifestyle}

Perkembangan teknologi dan informasi yang semakin maju membuat perubahan - perubahan pada perilaku masyarakat seperti halnya pada gaya hidup seseorang. Perubahan kebiasan masyarakat terutama mereka yang tahu teknologi dan informasi serta mereka yang berpenghasilan tinggi cenderung untuk menghabiskan waktu dan uang untuk berbelanja. Menurut Diah Pradiatiningtyas (2019 : 1) bahwa Shopping lifestyle merupakan pilihan seseorang dalam menghabiskan waktu dan uang. Ketersediaan waktu yang lebih banyak konsumen memiliki banyak kesempatan untuk berbelanja dan dengan uang yang tersedia mereka memiliki daya beli yang tinggi.

Menurut Diah Pradiatiningtyas (2019 : 1) yang dikutip dari Suwarman (2003) shopping lifestyle dapat diukur melalui:

1. Kegiatan (activities) yaitu cara hidup yang didefinisikan oleh bagaimana seseorang menghabiskan waktu mereka

2. Minat (interest) mencakup apa yang dianggap penting dalam lingkungannya

3. Opini (opinion) mencakup apa yang mereka pikirkan tentang diri mereka sendiri dan juga mengenai dunia disekitanya

\section{Positive Emotion}

Diah Pradiatiningtyas (2019 : 4) berpendapat bahwa emosi positif adalah emosi yang mampu menghadirkan perasaan positif terhadap seseorang yang mengalaminya. Emosi positif dapat didatangkan dari sebelum terjadinya mood seseorang, kecondongan sifat afektif seseorang dan reaksi pada lingkungan yang mendukung seperti ketertarikan pada item barang, pelayanan yang diberikan ke konsumen, ataupun adanya promosi penjualan. Konsumen dengan emosi positif menunjukan dorongan yang lebih besar dalam membeli karena memiliki perasaan yang tidak dibatasi oleh keadaan lingkungan sekitarnya, memiliki keinginan untuk menghargai diri mereka sendiri, dan tingkat energi yang lebih tinggi. Tingginya dorongan tersebut kemungkinan besar dapat terjadi pembelian secara implusif.

Menurut Diah Pradiatiningtyas (2019 : 4) yang dikutip dari (Mehrabian \& Russel,1974) mengenalkan pleasure, araousal dan dominance sebagai tiga dimensi dasar emosi yang menjelaskan perasaan seseorang terhadap lingkungannya.

1. Kesenangan (pleasure) mengacu pada tingkat dimana individu merasa senang, penuh kegembiraan, dan bahagia yang berkaitan dengan situasi tersebut

2. Antusias (araousal) mengacu pada perasaan individu saat tertarik, siaga, atau afektif dalam suatu situasi dimana ada rangsangan dari lingkungannya 
3. Pengendalian (dominance) mengacu pada perasaan pengendalian dan sejauh mana individu merasa dibatasi dalam perilakunya

\section{Impulse Buying}

Menurut Kollat \& Willett, 1967 dalam Sudarsono (2017 : 18) Impulse buying merupakan keputusan pembelian yang dilakukan di dalam toko dengan tidak adanya pengakuan eksplisit akan kebutuhan atas pembelian tersebut sebelum masuk ke toko. Pembelian impulsive biasanya timbul ketika konsumen berada di dalam toko dan di rangsang oleh stimuli eksternal (berupa produk yang dilihat) sehingga muncul keinginan dalam dirinya untuk segera membeli produk tersebut.

Menurut Beatty dan Ferrel, dalam Septiaan Wahyudi (2017) impulse buying diukur melalui 7 dimensi utama, yaitu sebagai berikut:

1. Desakan untuk belanja (Urge to Purchase)

Urge to purchase merupakan suatu dorongan atau hasrat yang dirasakan ketika membeli sesuatu secara tiba-tiba atau spontan. Impulse buying terjadi ketika konsumen mengalami dorongan atau desakan secara mendadak, kuat dan gigih untuk membeli beberapa hal segera. Dorongan kuat, kadang-kadang tak tertahankan atau sulit dihentikan, kecenderungan untuk bertindak tibatiba tanpa musyawarah. Walaupun sangat kuat dan terkadang tidak dapat ditolak namun tidak dapat dilakukan. Bahkan orang-orang menggunakan strategi yang sangat banyak untuk mendapatkan kontrol terhadap hasrat ini.

\section{Emosi Positif (Positive Affect)}

Pengaruh positif dipengaruhi oleh suasana hati yang sudah dirasakan sebelumnya, disposisi afeksi, ditambah dengan reaksi terhadap pertemuan lingkungan toko tersebut (misalnya, barang-barang yang diinginkan dan penjualan yang ditemui). Suasana hati yang positif (senang, gembira, dan antusias) menyebabkan seseorang menjadi murah hati untuk menghargai diri mereka, konsumen merasa seolah-olah memiliki lebih banyak kebebasan untuk bertindak, dan akan menghasilkan perilaku yang ditunjukan untuk mempertahankan perasaan yang positif.

3. Melihat-lihat Toko (In-Store Browsing)

In-store browsing merupakan komponen utama dalam proses pembelian implusif. Jika konsumen menelusuri toko lebih lama, konsumen akan cenderung menemukan lebih banyak rangsangan, yang akan cenderung meningkatkan kemungkinan mengalami impulse buying yang mendesak.

\section{Kesenangan Berbelanja (Shopping Enjoyment)}

Definisi shopping enjoyment mengacu pada kesenangan yang didapatkan dari proses berbelanja, dalam hal ini mengacu pada konteks berbelanja di dalam mall atau pusat perbelanjaan. Beberapa penelitian menunjukan bahwa pembelian implusif dapat mejadi upaya seseorang untuk meningkatkan depresi atau untuk menghibur diri sendiri.

\section{Ketersediaan Waktu (Time Available)}

Time available mengacu pada waktu yang tersedia bagi individu untuk berbelanja. Tekanan waktu dapat mengurangi impulse buying sebaliknya ketersediaan waktu secara positif terkait dengan melakukan aktivitas pencarian dalam lingkungan ritel dapat mengakibatkan impulse buying. Individu dengan lebih banyak waktu yang tersedia akan melakukan pencarian lagi.

\section{Ketersediaan Uang (Money Available)}

Money Available mengacu pada jumlah anggaran atau dana ekstra yang dimiliki oleh seseorang yang harus dikeluarkan pada saat berbelanja. Beatty dan Ferrel menghubungkan variabel ketersediaan uang secara langsung dengan impulse buying karena hal tersebut dinilai menjadi fasilitator untuk terjadinya pembelian terhadap suatu objek.

7. Kecenderungan Pembelian Impulsif (Impulse Buying Tendency)

Impulse buying tendency didefinisikan sebagai (1) kecenderungan mengalami dorongan yang secara tiba-tiba muncul untuk melakukan pembelian on the spot (2) desakan untuk bertindak atas dorongan tersebut dengan hanya sedikit pertimbangan atau evaluasi dari konsekuensi.

\section{Hubungan Antar Variabel}

\section{Hubungan Shopping Lifestyle dan Impulse Buying}

Dalam era globalisasi membawa masyarakat ke dalam perilaku yang konsumtif, dimana belanja menjadi lifestyle. Konsumen akan rela mengorbankan sesuatu demi mendapatkan produk yang diinginkan dan disenangi. Shopping lifestyle mencerminkan pilihan seseorang tentang bagaimana cara menghabiskan waktu dan uang. Jika Shopping lifestyle masyarakat tinggi maka akan meningkatkan Impulse Buying.

\section{Hubungan Positive Emotion dan Impulse Buying}

Seseorang dengan emosi yang positif menyebabkan orang tersebut memiliki gairah dalam berbelanja. 
Berbagai produk yang dinilai menarik akan dibeli meskipun tidak ada perencanaan sebelumnya. Orang tersebut menganggap bahwa pembelian yang dilakukan merupakan pelampiasan dari rasa senang yang di alaminya. Jika masyarakat dalam keadaan senang maka cenderung untuk menciptkan Impulse Buying.

\section{Hubungan Shopping Lifestyle dan Positive Emotion terhadap Impulse Buying}

Shopping lifestyle mencerminkan pilihan seseorang dalam menghabiskan waktu dan uang. Dengan ketersediaan waktu konsumen akan memiliki banyak waktu untuk berbelanja dan dengan uang konsumen akan memiliki daya beli yang tinggi. Faktor perasaan atau emosi merupakan konstruk yang bersifat fluktuatif Perasaan yang dirasakan seperti jatuh cinta, gembira, ingin memiliki, terpesona, dan antusias dan kecenderungan melakukan impulse buying. Konsumen dengan emosi positif akan memiliki motivasi membeli yang tinggi. Tingginya dorongan tersebut kemungkinan besar dapat terjadi pembelian secara implusif.

\section{Kerangka Pemikiran}

Shopping lifestyle adalah cara seseorang untuk mengalokasikan waktu dan uang untuk berbagai produk, layanan, teknologi, hiburan, pendidikan, sikap dan pendapat mereka tentang dunia dimana mereka tinggal. Dalam penelitian ini, shopping lifestyle menggunakan dimensi dari Suwarman (2003) dalam Diah Pradiatiningtyas, 2019 yaitu activities, interest, dan opinion.

Positive emotion dapat ditimbulkan oleh suasana hati individu yang sudah ada sebelumnya, disposisi afektif, dan reaksi terhadap lingkungan (misalnya item yang diinginkan, promosi penjualan). Dalam penelitian ini, dimensi yang digunakan bersumber dari Mehrabian dan Russel dalam dalam Diah Pradiatiningtyas, 2019. Dimensi-dimensi tersebut yaitu pleasure, arousal dan dominance.

Impulse buying adalah suatu kegiatan pembelian barang dan atau jasa yang tidak direncanakan sebelumnya, dan dengan sedikit atau tanpa pertimbangan mendalam, serta kurang memikirkan akibat atau manfaat produk, yang mana keputusan pembeliannya dilakukan ketika konsumen berada di dalam toko. Dalam penelitian ini, dimensi-dimensi yang digunakan dikemukakan oleh Beatty and Ferrel dalam Wahyudi (2017), yaitu Urge to Purchase, Positive Affect, In-Store Browsing, Shopping Enjoyment, Time Available, Money Available, dan Impulse Buying Tendecy. Dari uraian kerangka teoritis di atas, dibuat paradigma penelitian yaitu sebagai berikut:

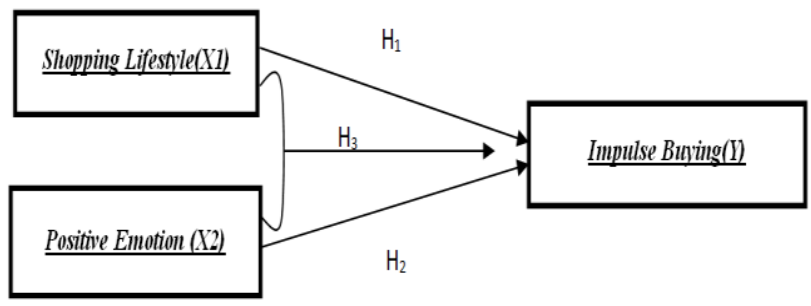

Gambar 1. Paradigma Penelitian

\section{Hipotesis}

$\mathrm{H} 1$ = Terdapat pengaruh yang signifikan antara shopping lifestyle terhadap impulse buying.

$\mathrm{H} 2$ = Terdapat pengaruh yang signifikan antara positive emotion terhadap impulse buying.

H3 =Terdapat pengaruh yang signifikan antara shopping lifestyle dan positive emotion terhadap impulse buying.

\section{METODE PENELITIAN}

Metode yang digunakan dalam penelitian ini adalah metode survei dengan pendekatan analisis deskriptif dan analisis verifikatif. Populasi dalam penelitian adalah konsumen toko UD Putra Tiga Saudara Majalengka yang berjumlah 200 orang sebagai sampel. Jenis data yang digunakan dalam penelitian ini yaitu data kualitatif yang dikuantitatifkan. Sumber data diperoleh dari data primer dimana data yang diambil secara langsung dari responden yaitu melalui pengisian kuesioner. Kuesioner yang disebarkan kepada konsumen sebanyak 26 pernyataan (6 pernyataan untuk Shopping Lifestyle, 6 pernyataan mengenai Positive Emotion dan 14 pernyataan untuk Impulse Buying). Cara menilai jawaban dari setiap kuesioner melalui sikap responden dengan skala skala likert. Pengujian instrumen penelitian dilakukan dengan Uji Validitas dan Reliabilitas. Selanjutnya dilakukan konversi dari data berskala ordinal ke data berskala interval dengan Method of Successive Interval(MSI) kemudian dilakukan Uji Normalitas Data. Analisis data yang digunakan melalui Analisis Regeresi Berganda, koefisien determinasi, Uji t dan Uji f.

\section{HASIL PENELITIAN DAN PEMBAHASAN}

\section{Profil Responden}

Pembahasan ini bertujuan untuk menggambarkan karakteristik demografi dari 200 orang responden yang dijadikan sampel pada penelitian ini. Karakteristik demografi tersebut adalah sebagai berikut: 


\section{Tabel 1 Profil Responden}

\begin{tabular}{llrr}
\hline No & Karakteristik & Jumlah & $\%$ \\
\hline 1 & Laki - Laki & 73 & 36.5 \\
2 & Perempuan & 127 & 63.5 \\
3 & $16-25$ tahun & 58 & 29,0 \\
4 & $26-40$ tahun & 125 & 62,5 \\
5 & $41-55$ tahun & 15 & 7,5 \\
6 & >55 tahun & 2 & 1.0 \\
7 & Pelajar/Mahasiswa & 33 & 16,5 \\
8 & PNS/TNI/POLRI & 12 & 6.0 \\
9 & Karyawan Swasta & 30 & 15.0 \\
10 & Ibu Rumah Tangga & 42 & 21.0 \\
11 & Berniaga/berdagang & 53 & 26,5 \\
12 & Lainnya & 30 & 15.0 \\
\hline \multicolumn{4}{l}{ (Sumber: Data Tabulasi Penelitian Tahun 2020) }
\end{tabular}

Berdasarkan tabel 1. di atas menunjukan bahwa responden yang digunakan dalam penelitian ini mayoritas berjenis kelamin perempuan, konsumen berada dalam rentang usia 26-40 tahun dan mereka mayoritas bekerja sebagai pedagang.

Hasil Tanggapan Shopping Lifesstyle Konsumen Toko UD Putra Tiga Saudara Majalengka Pengukuran Shopping Lifestyle dilakukan dengan memberikan 6 pernyataan kepada responden dengan rekapitulasi sebagai berikut :

Tabel 2. Rekapitulasi Jumlah Skor Tanggapan Responden Terhadap Shopping Lifestyle

\begin{tabular}{|c|c|c|}
\hline No. & Pernyataan & $\begin{array}{l}\text { Jumlah } \\
\text { Skor }\end{array}$ \\
\hline 1 & $\begin{array}{l}\text { Kegiatan berbelanja merupakan salah } \\
\text { satu aktivitas yang sering dilakukan }\end{array}$ & 741 \\
\hline 2 & $\begin{array}{l}\text { Dalam seminggu, } 2-3 \text { kali saya } \\
\text { menyempatkan waktu untuk } \\
\text { berbelanja }\end{array}$ & 743 \\
\hline 3 & $\begin{array}{l}\text { Ketertarikan terhadap produk dan } \\
\text { fasilitas yang tersedia }\end{array}$ & 742 \\
\hline 4 & $\begin{array}{l}\text { Ketertarikan terhadap produk yang } \\
\text { baru }\end{array}$ & 769 \\
\hline 5 & $\begin{array}{l}\text { Berbelanja merupakan salah satu } \\
\text { kegiatan untuk menunjukan status } \\
\text { sosial di masyarakat }\end{array}$ & 767 \\
\hline 6 & $\begin{array}{l}\text { Menyempatkan diri untuk berkunjung } \\
\text { ke tempat perbelanjaan merupakan } \\
\text { kebutuhan yang harus dipenuhi }\end{array}$ & 767 \\
\hline & Jumlah Skor & 4529 \\
\hline \multirow{2}{*}{\multicolumn{2}{|c|}{$\begin{array}{l}\text { Skor maksimum yang seharusnya tercapai } \\
\text { (Skor Maksimal } 5 \text { x } 6 \text { butir Pernyataan x } \\
200 \text { responden) }\end{array}$}} & 6000 \\
\hline & & $75.48 \%$ \\
\hline
\end{tabular}

(Sumber : Data Tabulasi Penelitian Tahun 2020

Berdasarkan tabel 2 di atas diperoleh jumlah skor sebesar 4.529 hal ini menunjukan bahwa konsumen menunjukan sikap Shopping Lifestyle sebesar $75.48 \%$ dan berada pada kriteria tinggi. Kondisi tersebut terlihat pada seringnya mereka berbelanja. Mereka dalam seminggu bisa 2-3 kali berbelanja.
Mereka selalu menyempatkan diri berbelanja karena menganggap aktivitas itu merupakan kebutuhan dan menunjukan status social mereka di masyarakat terlebih jika mereka mengetahui produk - produk yang tersedia itu menarik dan banyak produk baru yang ditawarkan.

Hasil Tanggapan Positive Emotion Konsumen Toko UD Putra Tiga Saudara Majalengka

Pengukuran Positive Emotion dilakukan dengan memberikan 6 pernyataan kepada responden dengan rekapitulasi sebagai berikut :

\begin{tabular}{|c|c|c|}
\hline \multicolumn{3}{|c|}{$\begin{array}{l}\text { Tabel } 3 \text { Rekapitulasi Jumlah Skor Tanggapan } \\
\text { Responden Terhadap Positive Emotion }\end{array}$} \\
\hline $\begin{array}{c}\text { No } \\
\text {. }\end{array}$ & Pernyataan & $\begin{array}{l}\text { Jumlah } \\
\text { Skor }\end{array}$ \\
\hline 1 & $\begin{array}{l}\text { Kenyamanan yang dirasakan pada saat } \\
\text { berbelanja membuat perasaan senang }\end{array}$ & 726 \\
\hline 2 & Produk yang dijual di toko memuaskan & 755 \\
\hline 3 & $\begin{array}{l}\text { Ketertarikan untuk berbelanja kembali } \\
\text { di toko yang sama }\end{array}$ & 787 \\
\hline 4 & $\begin{array}{l}\text { Bersemangat ketika berbelanja di toko } \\
\text { yang sama }\end{array}$ & 702 \\
\hline 5 & $\begin{array}{l}\text { Kemampuan mengendalikan diri atas } \\
\text { rangsangan berbelanja }\end{array}$ & 770 \\
\hline 6 & $\begin{array}{l}\text { Kemampuan mengendalikan diri ketika } \\
\text { membawa uang lebih }\end{array}$ & 787 \\
\hline \multirow{2}{*}{\multicolumn{2}{|c|}{$\begin{array}{l}\text { Jumlah } \\
\text { Skor maksimum yang seharusnya tercapai } \\
\text { (Skor Maksimal } 5 \text { x } 6 \text { butir Pernyataan x } \\
200 \text { responden) }\end{array}$}} & 4527 \\
\hline & & 6000 \\
\hline \multicolumn{2}{|c|}{ Persentase } & $\mathbf{7 5 . 4 5 \%}$ \\
\hline
\end{tabular}

Berdasarkan tabel 3 diperoleh jumlah skor sebesar 4.527 hal ini menunjukan bahwa konsumen menunjukan sikap positive emotion sebesar $75.45 \%$ dan berada pada kriteria tinggi. kondisi tersebut terlihat bahwa mereka merasa nyaman ketika berbelanja, konsumen merasa puas dengan produk yang dijual, konsumen bersemangat ketika berbelanja, konsumen merasa mampu mengendalikan diri ketika berbelanja dan konsumen lebih objektif berbelanja ketika membawa uang lebih.

\section{Hasil Tanggapan Konsumen Impulse Buying Konsumen Toko UD Putra Tiga Saudara Majalengka}

Pengukuran Impulse Buying dilakukan dengan memberikan 14 pernyataan kepada responden dengan rekapitulasi sebagai berikut: 


\begin{tabular}{|c|c|c|}
\hline No. & Pernyataan & $\begin{array}{l}\text { Jumlah } \\
\text { Skor }\end{array}$ \\
\hline 1 & $\begin{array}{l}\text { Membeli produk ketika ada penawaran } \\
\text { khusus (promo) }\end{array}$ & 774 \\
\hline 2 & $\begin{array}{l}\text { Berbelanja lebih banyak ketika ada } \\
\text { penawaran khusus (Promo) }\end{array}$ & 772 \\
\hline 3 & $\begin{array}{l}\text { Berbelanja lebih banyak ketika } \\
\text { memiliki mood yang baik }\end{array}$ & 758 \\
\hline 4 & $\begin{array}{l}\text { Merasa senang ketika melihat produk } \\
\text { yang diinginkan sejak dulu }\end{array}$ & 727 \\
\hline 5 & $\begin{array}{l}\text { Sebelum membeli produk yang } \\
\text { dibutuhkan, suka berkeliling toko } \\
\text { terlebih dahulu }\end{array}$ & 759 \\
\hline 6 & $\begin{array}{l}\text { Berlama - lama di dalam toko sering } \\
\text { dilakukan, meskipun sekedar duduk - } \\
\text { duduk dan bergurau. }\end{array}$ & 770 \\
\hline 7 & $\begin{array}{l}\text { Berbelanja merupakan kegiatan yang } \\
\text { menyenangkan }\end{array}$ & 766 \\
\hline 8 & $\begin{array}{l}\text { Berbelanja mampu menjadi aktivitas } \\
\text { untuk menyenangkan diri sendiri }\end{array}$ & 751 \\
\hline 9 & Menyempatkan waktu untuk berbelanja & 731 \\
\hline 10 & $\begin{array}{l}\text { Setiap ada waktu luang digunakan } \\
\text { untuk berbelanja }\end{array}$ & 748 \\
\hline 11 & $\begin{array}{l}\text { Setiap berbelanja selalu membawa uang } \\
\text { lebih untuk mengantisipasi harga } \\
\text { produk naik }\end{array}$ & 738 \\
\hline 12 & $\begin{array}{l}\text { Uang yang dibawa pada saat } \\
\text { berbelanja selalu habis dibelanjakan }\end{array}$ & 749 \\
\hline 13 & $\begin{array}{l}\text { Pada saat berbelanja sering lupa } \\
\text { terhadap produk yang seharusnya di } \\
\text { beli }\end{array}$ & 753 \\
\hline 14 & $\begin{array}{l}\text { Tidak berpikir panjang ketika membeli } \\
\text { produk }\end{array}$ & 759 \\
\hline Jum & & 10.555 \\
\hline \multicolumn{2}{|c|}{$\begin{array}{l}\text { Skor maksimum yang seharusnya tercapai } \\
\text { (Skor Maksimal } 5 \text { x } 6 \text { butir Pernyataan x } \\
\text { 200 responden) }\end{array}$} & 14000 \\
\hline \multicolumn{2}{|c|}{ Persentase } & $75.39 \%$ \\
\hline
\end{tabular}

Sumber: Data Tabulasi Penelitian Tahun 2020

Berdasarkan tabel 4 diperoleh jumlah skor sebesar 10.555 hal ini menunjukan bahwa perilaku konsumen dalam melakukan Impulse Buying sebesar 75.39\% dan berada pada kriteria tinggi. kondisi tersebut terlihat bahwa mereka merasa nyaman ketika berbelanja, konsumen merasa puas dengan produk yang dijual, konsumen bersemangat ketika berbelanja, konsumen merasa mampu mengendalikan diri ketika berbelanja dan konsumen lebih objektif berbelanja ketika membawa uang lebih.

\section{Pengaruh Shopping Lifestyle dan Positive Emotion Terhadap Impuls Buying}

Hasil pengolahan diperoleh dengan menggunakan software SPSS 21 adalah sebagai berikut:
Tabel 5 Hasil Analisis Regresi Linier Berganda

\begin{tabular}{|c|c|c|c|c|c|c|c|c|c|}
\hline \multicolumn{10}{|c|}{${\text { Coefficients }{ }^{a}}$} \\
\hline & \multirow[t]{2}{*}{ Model } & \multicolumn{2}{|c|}{$\begin{array}{c}\text { Unstandardized } \\
\text { Coefficients }\end{array}$} & \multirow{2}{*}{$\begin{array}{c}\text { Standardized } \\
\text { Coefficients } \\
\text { Beta }\end{array}$} & \multirow[t]{2}{*}{$t$} & \multirow[t]{2}{*}{ Sig. } & \multicolumn{3}{|c|}{ Correlations } \\
\hline & & B & $\begin{array}{c}\text { Std. Error } \\
2981\end{array}$ & & & & Zero-order & Partial & Part \\
\hline 1 & $\mathrm{X} 1$ & .570 & .103 & .364 & 5.525 & .000 & .371 & .366 & .363 \\
\hline & $\mathrm{X} 2$ & .180 & .105 & -113 & -1.710 & .089 & -137 & -121 & -112 \\
\hline
\end{tabular}

Tabel 6 Hasil Koefisien Deteminasi Secara Simultan

\begin{tabular}{|c|c|c|c|c|c|}
\hline \multicolumn{6}{|c|}{ Model Summary ${ }^{b}$} \\
\hline Model & $\mathrm{R}$ & R Square & $\begin{array}{c}\text { Adjusted R } \\
\text { Square }\end{array}$ & $\begin{array}{l}\text { Std. Error of the } \\
\text { Estimate }\end{array}$ & Durbin-Watson \\
\hline 1 & $.388^{a}$ & .150 & 142 & 4.868 & 995 \\
\hline
\end{tabular}

Tabel 7 Hasil Uji Hipotesis Secara Simultan

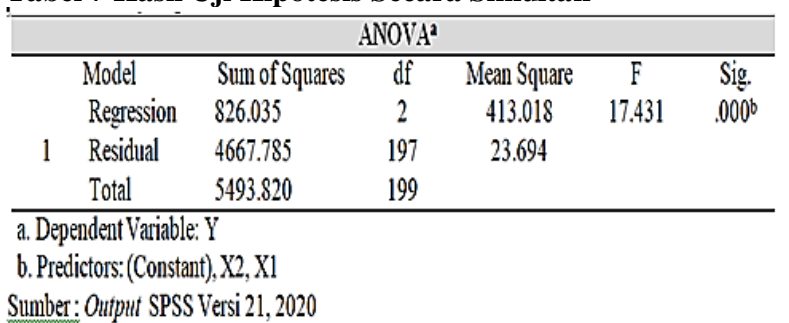

Berdasarkan tabel 5 menunjukan bahwa persamaan regresi linear berganda yang diperoleh dari hasil analisis yaitu $\mathrm{Y}=39.284+0,570 \mathrm{X}_{1}+0.180 \mathrm{X}_{2}$ maka dari persamaan di atas dapat diartikan sebagai berikut :

1. Konstanta $(\alpha)$ dalam regresi sebesar 39.284 dan bertanda positif artinya Impulse Buying bernilai 39.284 tanpa adanya pengaruh dari Shopping Lifestyle dan Positive Emotion

2. Koefisien regresi shopping lifestyle sebesar 0.570 dan bertanda positif, artinya setiap penambahan satu aktivitas shopping lifestyle akan Impulse Buying akan meningkat

3. Koefisien regresi positive emotion 0,180 dan bertanda negatif, artinya setiap penambahan satu aktivitas positive emotion maka akan impulse buying akan menurun

Selanjutnya dengan menggunakan analisis Koefisien determinasi dapat diketahui seberapa besar persentase kontribusi Shopping Lifestyle dan Positive Emotion terhadap Impulse Buying baik secara parsial maupun simultan.

Berdasarkan tabel 5 besarnya kontribusi Shopping Lifestyle mempengaruhi Impulse Buying yaitu sebesar $13,76 \%$. Meskipun nilai kontribusinya kecil namun nilai ini cukup berarti bagi peningkatan perilaku Impulse Buying. Artinya jika konsumen memiliki gaya hidup senang berbelanja maka senantiasa perilaku Impulse Buying ini akan meningkat. Hasil 
penelitian ini mendukung penelitian Edwin Japariyanto dan Sugiono Sugiharto (2011), Mega Usvita (2016) dan Diah Pradiatiningtyas (2019) yang menyatakan bahwa Shopping Lifestyle berpengaruh positif dan signifikan terhadap Impulse Buying.

Sementara pengaruh Positive Emotion terhadap Impulse Buying diperoleh nilai sebesar $1.88 \%$. Nilai ini menunjukan bahwa Positive Emotion tidak mampu mempengaruhi perilaku Impulse Buying. Artinya bahwa jika jika perasaan konsumen cenderung positif, maka tidak akan berdampak pada perilaku Impulse Buying. Konsumen akan lebih mampu berpikir rasional dan penuh pertimbangan dalam mengendalikan diri untuk membelanjakan uang dan mereka akan lebih memanfaatkan waktu luangnya untuk hal - hal yang lain daripada pergi tempat perbelanjaan. Tentunya hasil penelitian ini tidak sependapat dengan penelitian yang dilakukan oleh Jondry Adrin Hetharie (2012), Mega Usvita (2016), Jovinta Guntara Sudarsono (2017), Davota Ikanubun, Sri Murni Setyawati dan Nur Choirul Afif (2019) dan Diah Pradiatiningtyas (2019) yang menyatakan bahwa Positif Emotion berpengaruh terhadap Impulse Buying.

Namun, secara simultan berdasarkan pada tabel 6 dan 7 diatas diperoleh bahwa Shopping Lifestyle dan Positive Emotion berpengaruh terhadap Impulse Buying yakni sebesar 15\%. Artinya bahwa jika konsumen memiliki gaya hidup berbelanja disertai dengan perasaan positif, maka akan meningkatkan perilaku Impulse Buying. Melihat hal tersebut, maka sangat penting dan perlu adanya penelitian kembali dan menambah variabel lainnya sebagai Inductor:

\section{SIMPULAN DAN SARAN}

\section{Simpulan}

Berdasarkan hasil penelitian yang telah dilakukan, maka peneliti mengambil kesimpulan sebagai berikut:

1. Shopping lifestyle berpengaruh positif dan signifikan terhadap impulse buying dengan tingkat kontribusi $13.76 \%$. Artinya jika konsumen memiliki Shopping lifestyle yang tinggi maka perilaku impulse buyingnya senantiasa meningkat

2. Positive emotion tidak berpengaruh terhadap impulse buying dengan tingkat kontribusi hanya sebesar $1.88 \%$. Artinya tinggi rendahnya perilaku impulse buying pada konsumen tidak ditentukan oleh perasaan positifnya.

3. Shopping lifestyle dan positive emotion berpengaruh signifikan terhadap Impulse Buying dengan tingkat kontribusi sebesar $15 \%$. Artinya jika konsumen memiliki perilaku Shopping lifestyle yang tinggi dan sertai dengan positive emotion, maka akan perilaku Impulse Buying akan meningkat.

\section{Saran}

Berdasarkan kesimpulan hasil penelitian yang diperoleh di atas, maka beberapa saran yang dapat diberikan sebagai berikut :

1. Melihat tingginya perilaku konsumen mengenai Shopping Lifestyle, Positive Emotion dan Impulse Buying menjadi peluang yang sangat menjanjikan bagi perusahaan. Hal yang harus segera dilakukan berkaitan dengan variabel diatas yakni perusahaan harus mulai membuat program promosi seperti diskon harga, menambah lini produk yang lain seperti sepatu, sandal, alat - alat elektronik dan otomotif serta memaksimalkan lahan - lahan yang masih kosong sebagai prasarana rekreasi seperti tempat berphoto (Selfi) yang sedang menjadi tren saat ini.

2. Ruang lingkup penelitian ini masih terbatas, terletak pada 2 variabel independen, 1 objek penelitian dan alat analisis yang digunakan masih sederhana. Untuk penelitian selanjutnya kiranya masih sangat perlu adanya penelitian kembali denga ruang lingkup yang lebih luas seperti padapenambahan variabel independen seperti store atmosphere, 2-3 objek penelitian dan menggunakan alat analisis yang komplek.

\section{DAFTAR PUSTAKA}

A.A. Anwar, Prabu Mangkunegara. 2009. Perilaku Konsumen. Bandung: Refika.

Anggi M. Wijaya, Moh. Hufron dan A. R. Slamet. 2016. Pengaruh Shopping Lifestyle dan Fashion Involvement Terhadap Impulse Buying (Studi Kasus Pembelian Hijab Pada Mahasiswi Fakultas Ekonomi Universitas Islam Malang). E - jurnal Riset Manajemen Prodi Manajemen Fakultas Ekonomi Unisma.

Davota Ikanubun, Sri Murni Setyawati dan Nur Choirul Afif. 2019. Pengaruh Hedonic Shopping Terhadap Impulse Buying Yang Dimediasi Emosi Positif (Survei Pada Konsumen Toko Fashion di Kota "X"). Jurnal Ekonomi, Bisnis, dan Akuntansi, 21(1).

Diah Pradiatiningtyas. 2019. Analisa Pengaruh Hedonic Shopping Value, Shopping Lifestyle, Dan Positive Emotion Terhadap Impulse Buying Konsumen Dalam Melakukan Pembelian Online Di Marketplace. Journal Speed - Sentra 
Penelitian Engineering dan Edukasi - Volume 11 No 2 - Mei 2019

Edwin Japariyanto dan Sugiono Sugiharto. 2011. Pengaruh Shopping Lifestyle dan Fashion Involvement Terhadap Impulse Buying Behavior Masyarakat Hight Income Surabaya. Jurnal Manajemen Pemasaran, Vol. 6, No. 1, April $2011: 32-41$.

Jondry Adrin Hetharie. 2012. Peran emosi positif sebagai mediator stimulus lingkungan toko dan faktor sosial terhadap impulse buying tendency pada Matahari Departement Store Kota Ambon. Jurnal Aplikasi Manajemen, 10 (4), 890-89

Jovinta Guntara Sudarsono. 2017. Pengaruh visual merchandising terhadap impulse buying melalui positive emotion pada zara surabaya. Jurnal Manajemen Pemasaran, 11(1), 16-25.

Lizamary Angelina Darma dan Edwin Japarianto (2014). Analisa pengaruh hedonic shopping value terhadap impulse buying dengan shopping lifestyle dan positive emotion sebagai variabel intervening pada Mall Ciputra World Surabaya. Jurnal Manajemen Pemasaran, 8(2), 80-89

Mega Usvita. 2016. Pengaruh Hedonic Shopping Value, Shopping Lifestyle dan Positive Emotion Terhadap Impulse Buying Pada Plaza Andalas Padang. E - Jurnal Apresiasi Ekonomi Volume 4, Nomor 1, Januari $2016:$ 71-75.

Rachmawati. 2009. Hubungan antara Hedonic Shopping Value, Positive Emotion, dan Perilaku Impulse Buying pada konsumen ritel. Majalah Ekonomi. XIX(2): 192-209.

Septian Wahyudi. 2017. Pengaruh Price Discount terhadap Impulse Buying. Valuta, 3(2), 276-289. 
216 Coopetition, Vol XI, Nomor 3, Nopember 2020, 207 - 216 (E-ISSN : 2615-4978, P-ISSN : 2086-4620) 